\title{
A CHARACTERISATION AND EVALUATION OF URBAN AREAS FROM AN ENERGY EFFICIENCY APPROACH, USING GEOGRAPHIC INFORMATION SYSTEMS IN COMBINATION WITH LIFE CYCLE ASSESSMENT METHODOLOGY
}

\author{
S. GARCÍA-PÉREZ1 ${ }^{\text {, J. SIERRA-PÉREZ }}{ }^{2,3}$, J. BOSCHMONART-RIVES ${ }^{3}$, \\ G. LLADÓ MORALES ${ }^{4} \&$ A. ROMERO CALIX ${ }^{4}$ \\ ${ }^{1}$ Department of Urbanism and Planning, Escuela de Ingeniería y Arquitectura, Universidad de Zaragoza - Spain. \\ ${ }^{2}$ Centro Universitario de la Defensa de Zaragoza - Spain. \\ ${ }^{3}$ Sostenipra (ICTA - IRTA - Inèdit Innovació SL) 2014 SGR 1412. Institute of Environmental \\ Science and Technology (ICTA), Unidad de excelencia «María de Maeztu» \\ (MDM-2015-0552), Universitat Autònoma de Barcelona (UAB) - Spain. \\ ${ }^{4}$ Area Metropolitana de Barcelona (AMB) - Spain.
}

\begin{abstract}
The retrofitting of less energy efficient building stock represents one of the most significant challenges in the transition to a low-carbon economy. Nowadays, the housing sector represents about $40 \%$ of the energy consumption in the European Union. In this regard, the level of insulation installed in buildings is directly related to the energy efficiency of the building, and consequently to the urban area. In addition, several studies have shown that a comprehensive perspective of energy efficiency is needed, together with calculating the importance of introducing Life Cycle Assessment (LCA) methodology. The purpose of this study is to develop a methodology to: first, measure the energy efficiency level of specific urban areas and their buildings using a geospatial model in an integral perspective; and second, the environmental impact caused by the refurbishment of these building façades using a LCA method.

On the one hand, according to a bottom-up framework the quantitative and qualitative characterisation of the building stock façade at the urban scale is possible generating a georeferenced spatial data model of buildings using Geographic Information Systems. On the other hand, the environmental impact of the most usual constructive solutions to refurbishment building façades is calculated using the LCA methodology. The results obtained are merged and interpolated to the urban scale. The methodology is tested for the case study of blocks of flats in Barcelona using the open data of building stock from the Spanish Government. Firstly, this methodology provides more information in regard to urban areas as well as calculating their energy efficiency. Secondly, the study measures the renovation impact of the less efficient buildings. Finally, the results provide the basis for supporting decisions on building stock retrofitting for urban scale from a new approach, especially making the selection between various renovation scenarios much clearer.

Keywords: carbon footprint, façade, geographical information systems, life cycle assessment, retrofitting, Spain, urban scale.
\end{abstract}

\section{INTRODUCTION}

According to the European Union Framework Program Horizon 2020 the building sector represents one of the most significant challenges in the transition to a low carbon economy considering that more than $40 \%$ of the total energy consumption is accumulated by EU buildings [1], due to facilities and construction work. 
Though the building sector is not currently expanding, the European Union Directive 2012/27/EU [2] recognises that the rate of building retrofitting needs to be increased to reduce EU energy consumption. In this regard, one of the most effective solutions in retrofitting is to increase the level of insulation in buildings, because this is directly related to the energy efficiency of the buildings. However, several studies show that a comprehensive perspective of energy efficiency is needed, together with calculating the importance of introducing Life Cycle Assessment (LCA) methodology, also by retrofitting [3].

Recently, LCA has been applied to evaluate the environmental impact of the installation of thermal insulation in building façades [4], and also in façade retrofits [5]. However, the evaluation of the environmental impact of installing thermal insulation at the urban scale has rarely been studied within an LCA framework. To consider the environmental impact at the urban scale, knowledge of the current state of the building stock is essential.

Techniques to characterise building stock have been compared and classified by Swan \& Urgusal [6]. According to their classification the archetypes technique, a bottom-up approach, consists of modelling representative buildings and extrapolating their results to the urban scale. This has been used in recent studies for energy analysis [7, 8]. In addition, the new EU Directive 2003/98/CE [9] has contributed to developing a framework for the re-use of public sector information. This enables a new bottom-up approach to characterise the building stock at the urban scale, building-by-building, using public open data. The potential of Geographical Information Systems (GIS) to create geospatial data models in this new building-by-building approach has been explored in recent studies $[10,11]$. The combination of geospatial models and LCA at the urban scale has recently been developed by Mastrucci et al. to the Luxemburg context [12].

For the Spanish context, where the case study is placed, a lot of research has been focused on the characterisation of the building stock. Albert Cuchi \& Peter Swettman [13] through the Green Building Council Spain, and The Ministry of Development [14] have developed building stock studies using the census section scale, instead of the building-by-building approach. Moreover, the Metropolitan Area of Barcelona has started to use building-by-building bottom-up methodologies in combination with GIS to characterise the building stock for energy analysis at the urban scale (AMB, [15]). Nevertheless LCA methodology could be used to complete this study to provide a new holistic perspective.

The purpose of this study is to develop a methodology to obtain: first, the characterisation of the energy efficiency level of specific urban areas and their building, using a geospatial model in an integral perspective through a bottom-up approach using a new archetype technique in a building-by-building scale; and second, the environmental impact caused by the retrofitting of these buildings façade using an LCA method.

This methodology provides:

- More information in regards to urban areas as well as calculating the energy efficiency.

- A geospatial model that provides cartography in order to visualise results for stakeholders.

- The renovation cost of the less efficient buildings.

- The basis for supporting decisions on building stock retrofitting for urban scale from a new approach, specifically making the selection between various renovation scenarios by policy makers much easier.

The methodology is tested in the case study of the block of flats in Barcelona using the open data of building stock from the cadastre of the Spanish Government [16]. 


\section{METHODOLOGY}

The methodology includes three steps: (i) the characterisation of the building stock, (ii) the LCA and (iii) its extrapolation to the urban scale.

\subsection{Characterisation of the building stock}

Building-by-building characterisation includes two main steps: first, the classification of the building stock in qualitative categories; and then the quantitative characterisation, through the creation of a georeferenced spatial model of buildings using GIS, to obtain the geometrical conditions.

\subsubsection{Qualitative characterisation}

The qualitative characterisation involves two main categories: the year of construction and building typology, sufficient conditions at the urban scale to provide information on technical regulations on thermal insulation in buildings, and morphological and topological characteristics. The Spanish Government provides this data, from a public source, with a building by building scale through Cadastre [16, 17].

In regards to the study conducted by the Spanish Institute for Energy Diversification and Saving (IDEA) [18], there are three main variables to be considered depending on the year of construction: (i) buildings built before 1981, when there were no thermal insulation regulations; (ii) building built between 1981 and 2007, when the first regulations came into force, which demanded minimal thermal insulation requirements for individual building envelopes [19] and (iii) buildings built after 2008, when the Spanish Technical Building Code, which increased the minimum thermal insulation requirements, came into force.

Depending on the building typology there are three main variables: (a) Detached house, for a single family and is not joined to another house; (b) Terraced House, for a single family but is joined to another house and (c) Block of flats, for more than one family. This preliminary study considers the variable (c) block of flats (Table 1).

\subsubsection{Quantitative characterisation}

The georeferenced spatial model is developed in QGIS [22] and cartography and dataset obtained from the Spanish Government Cadastre.

- Firstly, for each building the method obtains by GIS: (i) the building footprint that represents the total surface area of roof of the building; (ii) the total perimeter; and (iii) the external perimeter.

Table 1: Qualitative characterisation.

\begin{tabular}{llcc}
\hline Category & \multicolumn{1}{c}{ Variable } & \multicolumn{1}{c}{ Regulations } & Source \\
\hline \multirow{3}{*}{ Year construction } & $\begin{array}{l}\text { (i) Built before 1981 } \\
\text { (ii) Built between 1981-2007 }\end{array}$ & $\begin{array}{c}\text { NBE-CT-79 [19] } \\
\text { (iii) Built after 2008 }\end{array}$ & Cadastre \\
& CTE-DB-HE [20] & \\
\hline \multirow{2}{*}{ Typology } & (a) Detached house & & \\
& (b) Terrace house & RD 1020/1993 [21] & Cadastre \\
& (c) Block of flats & & \\
\hline
\end{tabular}


- Secondly, the total Heated Floor Area (HFA) of each building is obtained from alphanumeric dataset from Cadastre. HFA is calculated, excluding Gloss Floor Area unheated areas such as garages, storage and industrial use from the total.

- Thirdly, the Medium Heated Height (MHH), that is defined by calculating the difference between HFA and the Building Footprint, multiplying by the average height between floors, 3 metres in the Spanish context [18].

With this data, the study then obtains the Gross Heated Façade Surface (GHFS), multiplying the external perimeter by MHH. However, hollows must be taken into account. Rodríguez-Soria et al. [23] characterised a standard block of flats in the Spanish context, calculating the hollows (windows and doors) percentage of the exterior wall surface, which is approximately $30 \%$. GHFS without hollows surface is called Net Heated Façade Surface (NHFS), and using this variable the study calculates the environmental impact of the least efficient façade retrofits.

\subsection{Life cycle assessment of façade retrofits}

This paper takes the LCA results from a study by Sierra-Pérez et al. [4, 5] of LCA of façade retrofits. LCA assessment was carried out to quantify the implications of thermal insulation in different façade systems from a cradle-to-site approach, whereby the environmental impact analysis includes the production (extraction and processing of raw materials, transport to manufacturers and manufacturing), transportation to the building site and the installation in the building according to EN 15804:2014 standards [24]. The software Simapro 7.3 and the Ecoinvent 3.1 database were used to this aim. The Environmental impact categories included in this study are the Global Warming Potential (GWP) and the Embodied Energy (EE) due to itsincreasing importance in building energy demand.

These studies define a Declared Unit (DU), which obtains the environmental impact of the production, transport, and installation of the necessary quantity of materials to retrofit $1 \mathrm{~m}^{2}$ of an existing building façade depending on: (i) type of thermal insulation, (ii) type of constructive solution, (iii) geographic location of the building and (iv) year of construction of the building.

\subsubsection{Types of thermal insulation}

Two types of thermal insulation are included in the study: expanded polystyrene (EPS), as one of the most commonly used in Spain; and Cork, a natural material of which $85 \%$ of its production is concentrated in the Iberian Peninsula [25].

\subsubsection{Types of façade retrofit included under study}

The study selected the following façade retrofit solutions, Ventilated façade (VF) system and ETICS (External Thermal Insulation Composite System), as they are not invasive and therefore does not interrupt the use of the building throughout the duration of the retrofit. They are the most common solutions in Spain. Moreover, both types of façades increase thermal insulation and eliminate thermal bridges in retrofitting. Figure 1 shows constructive details of façade systems selected according to Spanish Government Requirements Guide [26].

\subsubsection{Geographic location and year of construction of buildings}

The Spanish Technical Building Code established a thermal transmittance value $\mathrm{U}=0.29\left(\mathrm{~W} / \mathrm{m}^{2} \mathrm{~K}\right)$ for façades of new buildings located in a " $\mathrm{C}$ " climate zone, the climate zone in Barcelona [20]. 


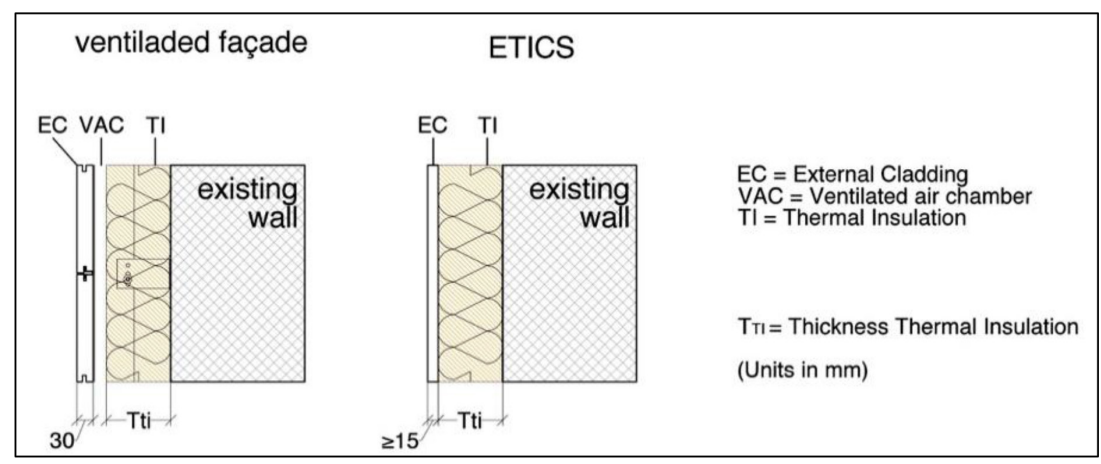

Figure 1: Constructive details of the façade systems studied.

Table 2: Declared unit $(\mathrm{kg})$ required of insulation per façade solution and year of construction to provide thermal resistance in "C" climate zone.

\begin{tabular}{|c|c|c|c|c|c|c|c|c|}
\hline & & & \multicolumn{6}{|c|}{ Unit per $\mathrm{m}^{2}$} \\
\hline $\begin{array}{l}\text { Geographic } \\
\text { location }\end{array}$ & \multicolumn{2}{|c|}{$\begin{array}{l}\text { U façade objective } \\
\left(\mathrm{W} / \mathrm{m}^{2} \mathrm{~K}\right)\end{array}$} & \multicolumn{6}{|c|}{0.29} \\
\hline \multirow{2}{*}{$\begin{array}{l}\text { Year of } \\
\text { construction }\end{array}$} & \multicolumn{2}{|l|}{ period } & \multicolumn{2}{|c|}{ before 1981} & \multicolumn{2}{|c|}{ 1981-2007 } & \multicolumn{2}{|c|}{ after 2008} \\
\hline & \multicolumn{2}{|c|}{$\begin{array}{l}\text { U façade estimated } \\
\left(\mathrm{W} / \mathrm{m}^{2} \mathrm{~K}\right)\end{array}$} & \multicolumn{2}{|c|}{3.00} & \multicolumn{2}{|c|}{1.80} & \multicolumn{2}{|c|}{0.73} \\
\hline \multirow[t]{3}{*}{ Material } & \multicolumn{2}{|c|}{ Type } & EPS & Cork & EPS & Cork & EPS & Cork \\
\hline & \multicolumn{2}{|c|}{$\begin{array}{l}\text { Thermal conductivity }(\lambda) \\
(\mathrm{W} / \mathrm{m} \mathrm{K})\end{array}$} & 0.035 & 0.042 & 0.035 & 0.042 & 0.035 & 0.042 \\
\hline & \multicolumn{2}{|c|}{ Density $\left(\mathrm{kg} / \mathrm{m}^{3}\right)$} & 35 & 171 & 35 & 171 & 35 & 171 \\
\hline \multirow{4}{*}{$\begin{array}{l}\text { Type of } \\
\text { façade } \\
\text { retrofit }\end{array}$} & \multirow[t]{2}{*}{ ETICS } & Thickness (m) & 0.11 & 0.13 & 0.10 & 0.12 & 0.07 & 0.08 \\
\hline & & Weight (kg) & 3.74 & 21.76 & 3.47 & 20.35 & 2.47 & 14.50 \\
\hline & \multirow{2}{*}{$\begin{array}{l}\text { Ventilated } \\
\text { façade }\end{array}$} & Thickness (m) & 0.10 & 0.13 & 0.10 & 0.12 & 0.07 & 0.08 \\
\hline & & Weight (kg) & 3.66 & 21.44 & 3.38 & 19.84 & 2.39 & 13.99 \\
\hline
\end{tabular}

The average thermal transmittance value of existing buildings in Spain is assumed (IDAE, [18]), and depends on the year of construction. In regards to this guide and the geographic location of the study three values were established: (a) buildings built before 1981 have a thermal transmittance estimated value $\mathrm{U}=3 \mathrm{~W} / \mathrm{m}^{2} \mathrm{~K}$; (b) buildings built between 1981 and $2007, \mathrm{U}=1,80 \mathrm{~W} / \mathrm{m}^{2} \mathrm{~K}$; and finally (c) buildings built after 2008, $\mathrm{U}=0,73 \mathrm{~W} / \mathrm{m}^{2} \mathrm{~K}$.

To calculate the environmental impact at the urban scale the research considers a scenario where all existing buildings achieve the effective value $\mathrm{U}=0,29 \mathrm{~W} / \mathrm{m}^{2} \mathrm{~K}$.

As described above, it is possible to calculate the declared unit $(\mathrm{kg})$ required of insulation per type of façade and year of construction within these parameters (Table 2). 


\subsection{Extrapolation at the urban scale}

On one hand NHFS $\left(\mathrm{m}^{2}\right)$ has been obtained for each residential building. On the other hand, the environmental impact of retrofit has been calculated from such impacts per $\mathrm{m}^{2}$. The data are then merged and therefore provides a direct extrapolation at different scales, from building by building, census section, neighbourhoods, to the city scale.

\section{RESULTS AND DISCUSSION}

\subsection{Characterisation of block of flats in Barcelona}

In Barcelona, 97\% of dwellings are located in blocks of flats. As revealed in Table 3, blocks of flats built before 1981, without thermal insulation regulations, are $84 \%$ of the total, whereas $15 \%$ correspond to blocks of flats built between 1981 and 2007, and only $2 \%$ are buildings built after 2008. These results are in line with other studies, and show that the more recent buildings tend to be built in the metropolitan area of Barcelona. Therefore, Barcelona contains a considerable amount of less efficient blocks of flats.

A direct relationship among a number of dwellings, NHFS and HFA are evident. However, establishing these parameters is crucial in order to identify and measure environmental impact.

As can be seen in Fig. 2, the methodology based on a building-by-building approach provides a geospatial model and is found to be advantageous to communicate results. The map shows a highly concentrated area of blocks of flats built before 1981 in the Example.

\subsection{Life Cycle Assessment of retrofitting}

The LCA of retrofitting $1 \mathrm{~m}^{2}$ of façade has been calculated. Figure 3 shows GWP $\left(\mathrm{kg} \mathrm{CO}_{2}-\mathrm{eq}\right)$ and Embodied Energy (MJ) impacts. Façade type is a significant factor: ETICS has less environmental impact than VF. Regarding thermal insulation, the graph shows that cork could be a better solution if GWP is taken into account. However, it is worse if Embodied Energy is analysed. In this case, the biogenic carbon contained in cork, a forest-based material is taken into account. This promotes the idea that the use of renewable material does not necessarily represent an overall environmental improvement and measures to optimize the use of resources and energy must be introduced. As can be seen in the graph, the year of construction is also an important factor. Environmental impact tends to decrease while regulations on thermal insulation have come into force.

Table 3: Characterisation of block of flats in Barcelona.

\begin{tabular}{lcccc}
\hline & Before 1981 & $1981-2007$ & After 2008 & TOTAL \\
\hline \multirow{2}{*}{ Number of dwellings } & 548.850 & 95.222 & 12.459 & 656.531 \\
& $84 \%$ & $15 \%$ & $2 \%$ & \\
NHFS $\left(\mathrm{m}^{2}\right)$ & 23.850 .731 & 3.840 .463 & 491.012 & 28.182 .206 \\
& $85 \%$ & $14 \%$ & $2 \%$ & \\
HFA $\left(\mathrm{m}^{2}\right)$ & 64.786 .240 & 11.957 .910 & 1.442 .295 & \multirow{2}{*}{$* 18.186 .445$} \\
\hline
\end{tabular}




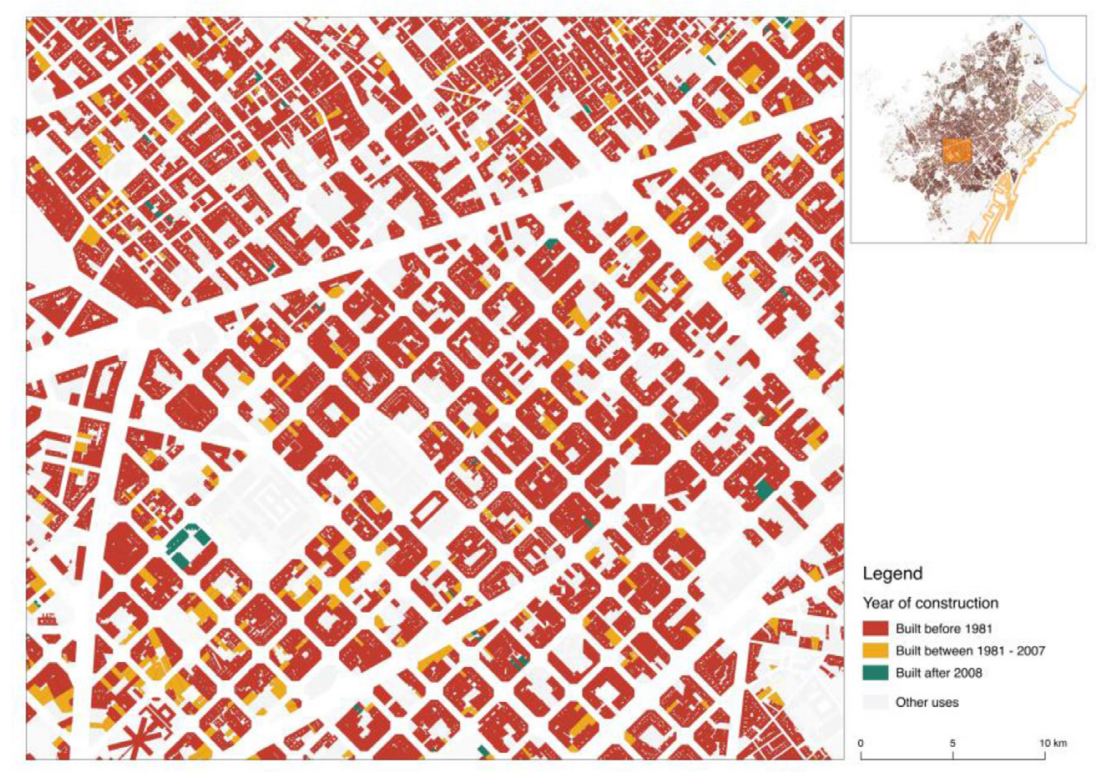

Figure 2: Map of year of construction of block of flats in an area of Barcelona.
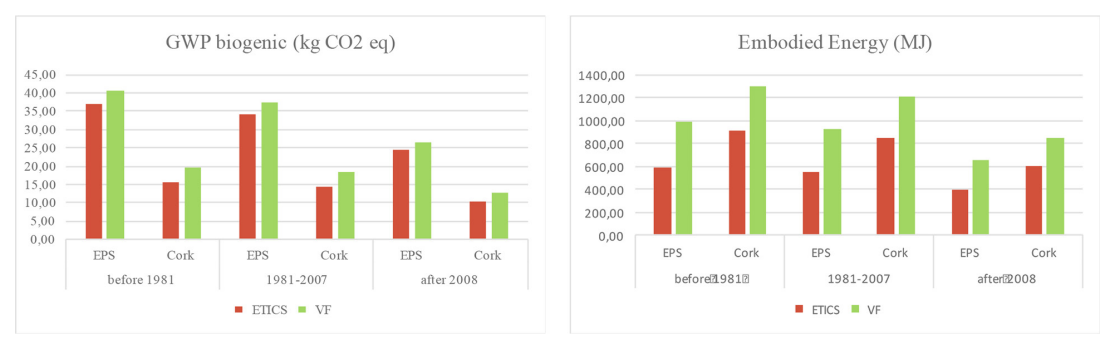

Figure 3: Environmental impact of $1 \mathrm{~m}^{2}$ of façade retrofit.

Figure 4 shows an example of an environmental impact map. In this case, the map draws the total GWP of ETICS - Cork façade retrofitting per block of flats. Whereas Fig. 2 shows a more uniform area, this map draws from a more mixed area. Different heights, HFA and NHFS provide diversity to a similar urban pattern (the Example).

Extrapolating the results at the urban scale, four different scenarios are obtained depending on the type of façade and thermal insulation. The year of construction is also a relevant variable. Figure 5 analyses these scenarios regarding two different impact factors: GWP and Embodied Energy. The most significant impact is concentrated in blocks of flats built before 1981, as shown. In Fig. 5, depending on the façade type and thermal insulation, there are differences of more than 50\% between scenarios. Embodied Energy of ETICS EPS is $46 \%$ less than VF in combination with cork. GWP ETICS with cork has $40 \%$ less ton $\mathrm{CO}^{2}$-eq. than VF with EPS. This amount demonstrates the relevance of a holistic point of view and the importance of using LCA methodologies at the urban scale. 


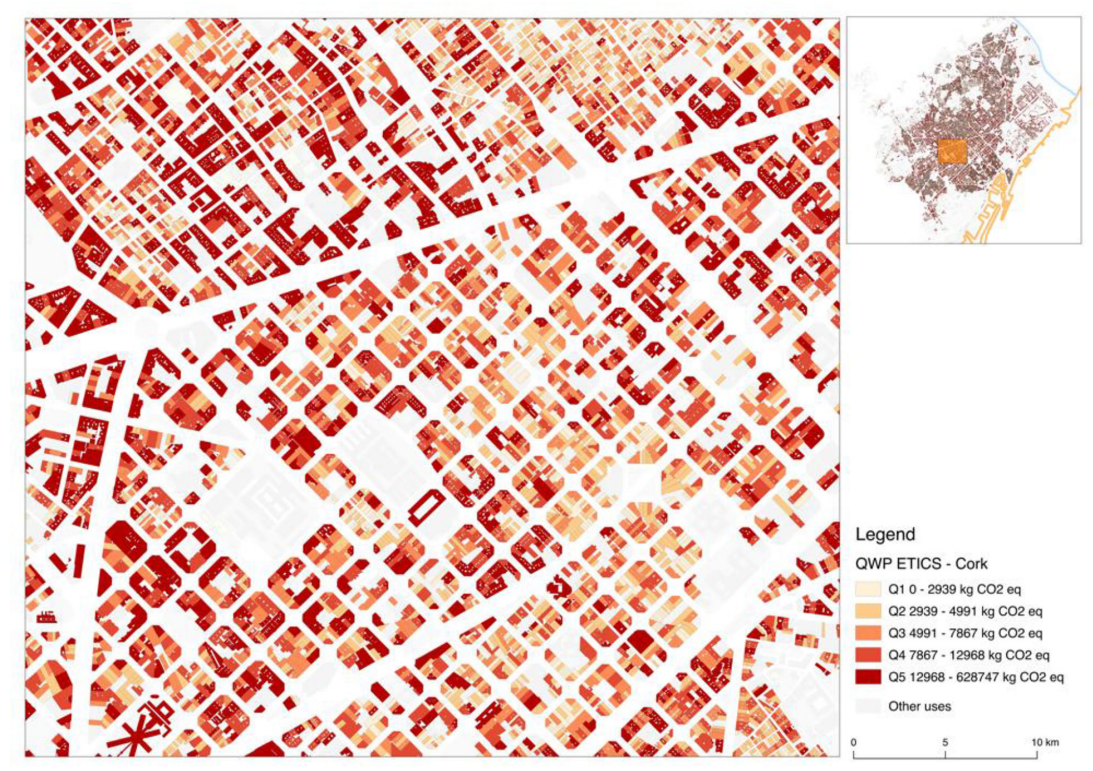

Figure 4: Map of total GWP of ETICS - Corks façade retrofitting per block of flats in an area of Barcelona.
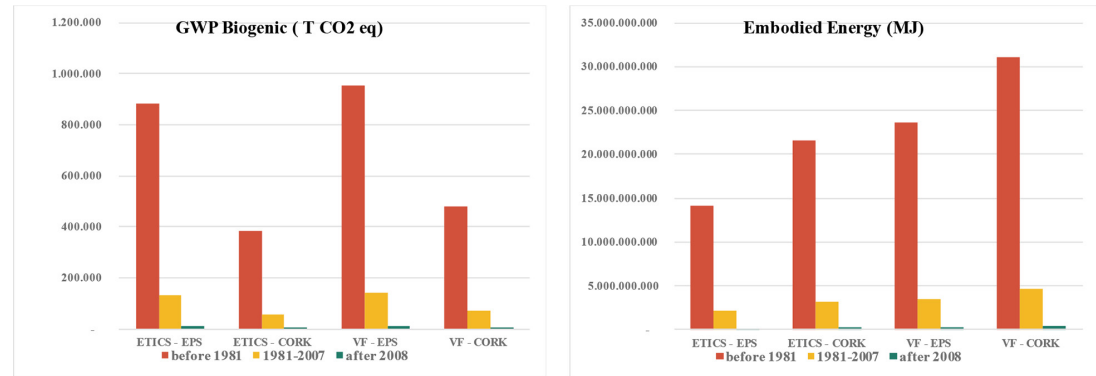

Figure 5: Impact factors at the urban scale.

\section{CONCLUSION}

A geospatial model for the LCA of building façade retrofits at the urban scale was developed. This preliminary approach provides firstly a new methodology to characterise building stock, tested in the case study of blocks of flats of Barcelona according to the Spanish Government dataset. The results contribute to update and increase knowledge on building stock. Using GIS, the methodology obtains maps as results. Therefore, it may be a significant tool to communicate with retrofit stakeholders.

Secondly, extrapolating the environmental impact of construction systems at the urban scale allows on the one hand measure retrofit impact on an entire city, and on the other hand define different retrofit scenarios, facilitating decisions for policy makers.

Further steps may take into account all envelope surfaces, for instance roof type retrofit, to have a deeper knowledge about the environmental impact of retrofitting. Comparing different 
retrofitting scenarios would be developed in future research. Cork as a natural thermal insulation material would be studied in a real scenario, taking into account real material resources.

Finally, combining different dataset (energy performance certificates, wider typology studies...) into a common geospatial model could provide a more precise knowledge for future research.

\section{ACKNOWLEDGMENTS}

The work has been substantially supported by the Metropolitan Area of Barcelona (AMB) in terms of grants for environmental research.

\section{REFERENCES}

[1] European Comission, Energy performance of Buildings Directive 2010/31/EU (EPDB) 2010.

[2] European Comission, Energy Efficiency Directive 2012/27/EU 2012.

[3] Çomaklı, K. \& Yüksel, B., Optimum insulation thickness of external walls for energy saving. Applied Thermal Engineering, 23, pp. 473-479, 2003.

http://dx.doi.org/10.1016/S1359-4311(02)00209-0

[4] Sierra-Pérez, J., Boschmonart-Rives, J. \& Gabarrell, X., Environmental assessment of façade-building systems and thermal insulation materials for different climatic conditions. Journal of Cleaner Production, 113, pp. 102-113, 2016.

http://dx.doi.org/10.1016/j.jclepro.2015.11.090

[5] Sierra-Pérez, J., Boschmonart-Rives, J., Guillén-Lambea, S., Rodriguez-Soria, B. \& Gabarrell, X., Environmental implications of cork as thermal insulation in façade retrofits. 10th Conference: Advanced Building Skins Conference, Bern, 2015.

[6] Swan, L.G. \& Ugursal, V.I., Modeling of end-use energy consumption in the residential sector: a review of modeling techniques. Renewable \& Sustainable Energy Reviews. 13, pp. 1819-1935, 2009. http://dx.doi.org/10.1016/j.rser.2008.09.033

[7] Mata, É., Sasic Kalagasidis, A. \& Johnsson, F., Building-stock aggregation through archetype buildings: France, Germany, Spain and the UK. Build Environement, 81, pp. 270-282, 2014.

http://dx.doi.org/10.1016/j.buildenv.2014.06.013

[8] Tuominen, P., Holopainen, R., Eskola, L., Jokisalo, J. \& Airaksinen, M., Calculation method and tool for assessing energy consumption in the building stock. Build Environement, 75, pp. 153-160, 2014.

http://dx.doi.org/10.1016/j.buildenv.2014.02.001

[9] European Comission, Re-use of public sector information Directive 2003/98/EC 2003.

[10] Mavrogianni, A., Davies, M., Kolokotroni, M. \& Hamilton, I., A GIS-based bottom-up space heating model of the London domestic stock. Elev. International IBPSA Conference, Glasgow, pp. 1061-1067, 2009.

[11] Österbring, M., Mata, É., Jonsson, F. \& Wallbaum, H., A methodology for spatial modelling of energy and resource use of buildings in urbanized areas. World Sustainable Building Conference WSB14, Barclona, 2014.

[12] Mastrucci, A., Popovici, E., Marvuglia, A., Benetto, E. \& Leopold, U., GIS-based life cycle assessment of urban building stocks retrofitting. a bottom-up framework applied to luxembourg. 29th International Conferences Informatics Environmental Protection 
(EnviroInfo 2015) - Third International Conferences ICT Sustainability (ICT4S 2015), pp. 47-56, 2015.

[13] Cuchí, A. \& Sweatman, P., Una visión-país para el sector de la edificación en españa,70, 2011.

[14] Ministerio de Fomento, Análisis de las características de la edificación residencial en España (2001), Madrid, 2013.

[15] Direcció de Serveis Ambientals de l'AMB, Anàlisis dels Teixits Urbans del L'AMB, Barcelona: AMB; 2015.

[16] Dirección General del Catastro, Fichero informático de remisión de catastro (bienes inmuebles urbanos, rústicos y de características especiales), 18, 2011.

[17] Dirección General del Catastro, Modelo de datos de cartografía vectorial (formato shapefile), 2013.

[18] IDAE, Guía IDAE: Manual de fundamentos técnicos de calificación energética de edificios existentes CE3X, Madrid, 2012.

[19] Ministerio de Obras Públicas y Urbanismo, Real Decreto 2429/79, de 6 de julio, por el que se aprueba la Norma Básica de la Edificación NBE-CT-79, sobre Condiciones Térmicas en los edificios, 1979.

[20] Codigo Tecnico de la Edificación (CTE), Documento Básico de Ahorro de Energía (DB-HE) 2006.

[21] BOE, Real Decreto 1020/1993, de 25 de junio, por el que se aprueban las normas técnicas de valoración y el cuadro marco de valores del suelo y de las construcciones para determinar el valor catastral de los bienes inmuebles de naturaleza urbana, Spain, 1993.

[22] QGIS Development Team, QGIS Geographic Information System, Open Source Geospatial Found Proj, 2015.

[23] Rodríguez-Soria, B., Domínguez-Hernández, J., Pérez-Bella, J.M. \& del Coz-Díaz, J.J., Quantitative analysis of the divergence in energy losses allowed through building envelopes. Renewable and Sustainable Energy Reviews, 49, pp. 1000-1008. http://dx.doi.org/10.1016/j.rser.2015.05.002

[24] European Committee for Standardization. EN 15804:2012+A1, 2013. Sustainability of construction works - Environmental product declarations - Core rules for the product category of construction products. 2014.

[25] Sierra-Pérez, J., Boschmonart-Rives, J. \& Gabarrell, X., Production and trade analysis in the Iberian cork sector: economic characterization of a forest industry. Resource Conservation and Recycling, 98, pp. 55-66, 2015.

http://dx.doi.org/10.1016/j.resconrec.2015.02.011

[26] Ministerio de Vivienda, Instituto de Ciencias de la Construcción EduardoTorroja, CSIC. Catálogo de elementos constructivos del CTE, 141, 2008. 